\title{
Temporal Variability of Theft Types in the Historic Centre of Porto
}

\author{
Vanessa Azevedo ${ }^{1,2} \mathbb{D}^{\mathbb{D}}$, Mariana Magalhães ${ }^{1} \mathbb{D}$, Daniela Paulo ${ }^{1} \mathbb{D}$, Rui Leandro Maia ${ }^{1,2} \mathbb{D}^{\mathbb{D}}$, Gisela M. Oliveira $^{3} \mathbb{D}$, \\ Maria Simas Guerreiro ${ }^{2,3} \mathbb{D}$, Ana Isabel Sani ${ }^{1,2,4} \mathbb{D}$ and Laura M. Nunes $1,2,5, *$
}

1 Faculty of Human and Social Sciences, University Fernando Pessoa (UFP), 4249-004 Porto, Portugal; vazevedo@ufp.edu.pt (V.A.); m.maia.magalhaes@gmail.com (M.M.); adanielapsoares@gmail.com (D.P.); rlmaia@ufp.edu.pt (R.L.M.); anasani@ufp.edu.pt (A.I.S.)

2 Observatory Permanent Violence and Crime (OPVC), University Fernando Pessoa (UFP), 4249-004 Porto, Portugal; mariajoao@ufp.edu.pt

3 Fernando Pessoa Energy, Environment and Health Research Unit (FP-ENAS), University Fernando Pessoa (UFP), 4249-004 Porto, Portugal; gisela@ufp.edu.pt

4 Research Center on Child Studies (CIEC), University of Minho (UM), 4710-057 Braga, Portugal

5 Centro de Investigação em Justiça e Governação (JusGov), University of Minho (UM), 4710-057 Braga, Portugal

* Correspondence: lnunes@ufp.edu.pt

check for updates

Citation: Azevedo, Vanessa, Mariana Magalhães, Daniela Paulo, Rui Leandro Maia, Gisela M. Oliveira, Maria Simas Guerreiro, Ana Isabel Sani, and Laura M. Nunes. 2021. Temporal Variability of Theft Types in the Historic Centre of Porto. Social Sciences 10: 371. https://doi.org/ 10.3390/socsci10100371

Academic Editor: Nigel Parton

Received: 3 August 2021

Accepted: 22 September 2021

Published: 1 October 2021

Publisher's Note: MDPI stays neutral with regard to jurisdictional claims in published maps and institutional affiliations.

Copyright: (c) 2021 by the authors. Licensee MDPI, Basel, Switzerland. This article is an open access article distributed under the terms and conditions of the Creative Commons Attribution (CC BY) license (https:/ / creativecommons.org/licenses/by/ $4.0 /)$.
Abstract: Criminology theories imply that time is a relevant variable, especially for the prevention and intervention of criminal occurrences. Thus, the study of criminal temporal patterns has been described as being of great relevance. The present study focuses on describing and exploring the influence of temporal and seasonal variables on the occurrence of different types of theft in the Historic Centre of Porto through the analysis of official records of the Public Security Police. Significant differences were found regarding the time of day and season of occurrence, even though it is not observed for all the types of theft analysed. Overall, theft was more prevalent at night and less frequent during winter, which is congruent with previous literature and the routine activity theory. Being the first case study in Porto city, Portugal, this research may be of extreme importance for both designing prevention and intervention policies in the area, and for inspiring future research on a criminal time analysis.

Keywords: urban criminality; thefts; official police records; seasonality analysis; temporal analysis

\section{Introduction}

A population's migration to urban areas is triggered by people's desire to search for a better standard of living; nevertheless, the growth of urban population has also undesirable outcomes (Oliveira et al. 2020). In conjunction with the absence of an adequate infrastructure, the increase in population disturbs citizens' public health and well-being, in addition to social and economic disparities, and sustainability issues, for instance overpopulation, traffic flow, pollution, frenetic everyday life, poverty, enlarged cost of living, and lastly, crime (Cozens 2007; Nunes et al. 2017; Maia and Estrada 2017; Sani and Nunes 2016).

According to environmental criminology, criminal activity occurs with the involvement of an offender, a target, and a place. It is based on the premise that everyone is expected to be at a certain location and moment in time, so crime is distributed across place and time (Ratcliffe 2006). Crime seems to be concentrated on specific times and places throughout the city, emphasizing the notion of "hot spots" of crime that refers to where and/or when crime and/or fear of crime are highly focused (Sherman et al. 1989). Nevertheless, there are changes in the immediate environment that can either encourage or inhibit crime occurrences (e.g., hours of daylight, meteorological conditions) that force individuals to adapt their daily activities (Cohen and Felson 1979). These variables influence 
human behaviour, being this the groundwork for the research of seasonality and climate's impact on crime.

The routine activity (RA) theory (Cohen and Felson 1979), the most common theory to enlighten this subject, establishes that a crime takes place when there is a convergence in space and time of motivated offenders, suitable targets, and the absence of capable guardians against a violation. This approach is based on the premise that the usage of personal time changes over time and can influence criminal opportunities. For instance, people tend to devote more time outdoors when the weather is more enjoyable, during the warmer months, which leads to more criminal opportunities since it enhances personal interaction and individuals' houses are left empty, vulnerable, and unprotected. On the other hand, during colder months people spend more time at home, consequently, there are less people in the streets, reducing suitable targets meaning they are more vulnerable and fewer chances to deter the perpetrator. In addition, there are activities which are specifically linked to a time of year, such as school vacations and sports, altering how individuals use their time (Haberman et al. 2017). Everyday activities have either a certain duration (e.g., school attendance, work) or a flexible duration (e.g., shopping, recreational time) that frequently happens simultaneously (Cohen and Felson 1979; Ratcliffe 2006).

Both seasonality and meteorologic conditions' influence on criminality have been studied for a long time (e.g., Breetzke and Cohn 2012; Ceccato 2005; Cohn 1990; Cohn and Rotton 2000; Farrell and Pease 1994; Linning et al. 2016; Morken and Linaker 2000), mostly motivated by the availability of both climate and crime data, in combination with the geographical information systems and geographic information science's expansion (Ratcliffe 2006; Schutte and Breetzk 2018). A better understanding of crime's seasonality and climate's influence on crime promotes implementations of more efficient policies, as it helps to identify the appropriate moment to implement crime prevention measures (Andresen and Malleson 2013).

Lombroso (1911, cited in Cohn 1993) studied the impact of temperature, months, seasons, and meteorological influences on crime. Guerry de Champneuf focused on the effect of variations in climate and seasons on criminality to reach the conclusion that crime against persons occurred most during the summer, while in the winter crimes against property were recorded more (Elmer 1933, cited in Cohen 1941), which is congruent with other studies (Dexter 1904, cit. in Falk 1952; Lombroso 1911; Ferri 1882, 1926, cited in Cohen 1941; Aschaffenburg 1913, cited in Cohen 1941), and was confirmed through Adolphe Quetelet's thermal law (1842, cited in Cohen 1941) according to which it was verified that crimes against persons were more common in warmer regions and periods and crime against property were more prevalent in colder areas and in the winter. As crime typologies seem to be a relevant factor for crime seasonality (Andresen and Malleson 2015), we focus on property crime.

Even though several studies have been performed regarding crime seasonality, few have focused on property crime. Across several European countries and the United States of America, property crimes are reported more during the winter (DeFronzo 1984; Field 1992). However, Falk (1952) stated that property crimes do not always occur most in the winter, as it does not also reach its minimum occurrence in the summer. Additionally, other studies demonstrated that summer peaks were also observed, on contrary to Queletet's thermic law (Anderson 1987; Cohn and Rotton 2000; Schutte and Breetzk 2018). In general, in cities that go through more weather variations during the whole year, more property crimes are committed over the summer (Linning et al. 2016).

Temperature has for a long time been linked to crimes against property (Brunsdon et al. 2009; Cohn and Rotton 2000; Field 1992; Hart et al. 2019; Rotton and Cohn 2003), even though several other studies failed to show a relationship between these variables (Anderson et al. 1997; Cotton 1986). In China, Hu et al. (2017) found a positive association between temperature and property crimes. Hipp et al. (2004) discovered that crimes against property are more frequent in pleasant weather. The RA theory may be an explanation for the increase in property crimes during warmer weather (the summer season) than in other 
times of the year, as people tend to spend more time outdoors (Cohn and Rotton 2000; Rotton and Cohn 2003; Schutte and Breetzk 2018).

Additionally, rainfall has also been suggested to be a pertinent factor in criminality, despite that its influence differs by type of crime (McLean 2007; Sommer et al. 2018). Property crimes are perpetrated with the sole purpose of acquiring property and involve planning, that in turn, can be disturbed by high rainfall. Based on the RA theory, precipitation can lead to an increase individuals' choice to stay at home which decreases crime levels (Schutte and Breetzk 2018). However, it might only reduce crime occurrences during the rainfall, consequently delaying crime (Field 1992). Nevertheless, consensus was not reached regarding precipitation being a predictor of crime (Brunsdon et al. 2009; Field 1992) or not having an impact as significant as temperature (Wu et al. 2019), as some studies report a small increase in prevalence (Schutte and Breetzk 2018), while others indicated decreases (Baryshnikova et al. 2019).

Specifically focusing on theft offences, temperature and seasonality seem to be significantly associated (Cohn and Rotton 2000; Rotton and Cohn 2003; Stevens et al. 2019). Several studies have demonstrated that this crime occurs more frequently in the summer (Cohn and Rotton 2000; McDowall et al. 2012), which can be justified by tourism's rise throughout the summer season (Sypion-dutkowska 2015). Apart from this explanation, other authors' conclusions drawn from the spatial concentration of crime show that most occurrences take place in popular locations, such as traditional shopping streets (Stevens et al. 2019), at trendy beaches and parks, locations with water activities and other leisure and recreational places such as summer fairs (Andresen and Malleson 2013). Once again, there is no consensus regarding the time of the year with the highest prevalence: while some studies reported higher prevalence during summer and lowest during winter (Andresen and Malleson 2013; Stevens et al. 2019), others reported a peak during autumn (Falk 1952) or winter (Cohen 1941), and the lowest prevalence during February (Falk 1952). However, other research studies indicated a non-existence of a seasonal pattern for thefts (DeFronzo 1984; Yan 2004) or a weaker seasonal pattern (Field 1992). Concerning rainfall and theft offences, it seems that the first is not a significant predictor of the second (Mapou et al. 2017).

Concerning pickpocketing offences, there is a weak summer peak (Yan 2004). Lab and Hirschel (Lab and Hirschel 1988, cit. in Lab and Hirschel 1988) indicated that there are fewer occurrences in inclement weather, which can be caused by the decrease in outdoor activities. Additionally, Papaioannou (2017) indicated that extreme rainfall can lead to a significant growth in prevalence.

Motor vehicle thefts are not significantly associated with either temperature (DeFronzo 1984; Rotton and Cohn 2003) or seasonal variations (Farrell and Pease 1994). Some studies show an increase during winter months (Cohen 1941; Linning 2015; Sypion-dutkowska 2015). Aligned with these findings, Falk (1952) demonstrated that these offences occur mostly in January and, in a smaller degree, in May. On the opposite, Andresen and Malleson (2013) indicated a prolonged peak in summer and autumn seasons, reaching its lowest level during winter. Moreover, a recent study reported a higher prevalence of motor vehicle thefts during both the coldest and warmest months (Mares and Moffett 2019). Precipitation appears not to be significantly associated with this crime (Mapou et al. 2017).

Theft in a motor vehicle is described to happen more frequently during the summer and autumn seasons, as well as in January, which can be explained by a delay in reporting occurrences that happen during Christmas holidays (Andresen and Malleson 2013). When considering spatial concentration, both motor vehicle thefts and thefts in motor vehicles tend to occur at popular places, such as beaches, parks, and other leisure and recreational places (Andresen and Malleson 2013).

Thefts in commercial buildings, with or without a break-in, appear to be regular throughout the year (Sypion-dutkowska 2015). There is a tendency to demonstrate a seasonal peak later in the year (Linning 2015), therefore in the winter months (Linning et al. 2016; Yan 2004). 
Residential thefts were related to temperature by several works (Lab and Hirschel 1988; Rotton and Cohn 2003), appearing to occur mostly when temperatures are higher (DeFronzo 1984; Peng et al. 2011), although other research show no association (Hu et al. 2017; Ranson 2014). Seasonality is likewise related (Cohn and Rotton 2000; Peng et al. 2011), as this type of crime tends to peak during the summer because it happens indoors. Due to summertime activities, individuals spend less time at home, which becomes ideal targets for offenders (McDowall et al. 2012). Andresen and Malleson (2013) reported the lowest rate of burglaries in February, with an increase rate until its peak in late spring, and constant for the rest of the year. Other studies reported an increase during winter months (Cohen 1941; Field 1992; Sypion-dutkowska 2015), in agreement with Farrell and Pease's findings (1994). According to this study, domestic burglary records are higher in the first four months of the year, especially in February and March (colder months), and lowest in July or August (warmest months). Nevertheless, other studies showed an absence of seasonal variations for burglary (Yan 2004). Regarding precipitation, literature indicates either a positive significant (Lab and Hirschel 1988) or an absent (Cohn and Rotton 2000; Mapou et al. 2017) relationship between these variables.

Considering what has been documented regarding mixed findings about the influence of seasonality and meteorological variables on crime prevalence (especially thefts) and the absence of empirical studies on these topics in Portugal, the present study aims to analyse how seasonality and weather conditions alter the prevalence of different types of theft, based on official reports and statistics.

\section{Methods}

\subsection{Study Area}

The city of Porto covers an area of $41.42 \mathrm{~km}^{2}$, including seven parishes and is the second most populated city of Portugal (namely 231,962 inhabitants, with a density population of 5200 inhab $/ \mathrm{km} 2$ ). It is located in the North of Portugal, which has a Mediterranean climate and is the fourth safest country according to the Global Peace Index (Institute for Economics and Peace 2021). Recently awarded the Best European Destination, according to the information provided by PORDATA (2021), between 2015 and 2019, the number of tourist accommodations increased from 164 to 373, the number of overnights by 100 inhabitants increased from 1330.8 to 2143 , and the tourism profits increased from EUR 139.524 thousand to EUR 292.135 thousand. Based on the information available at the Porto City Hall, the number of tourists in 2018 was 3.3 million. Concerning crime, Porto presents the second highest value on the number of criminal occurrences, with a decrease between 2015 $(\mathrm{N}=62,028)$ and $2019(\mathrm{~N}=57,879)$ (Sistema de Segurança Interna 2016, 2020). Situated at the riverbanks of Douro, this study's target area is the Historic Centre of Porto (HCP), which was established as World Heritage by UNESCO in 2008, an urban area characterized by ancient architectural buildings that emphasizes its millennial historical development. Therefore, a high percentage of buildings require urgent repairs, even though urban requalification efforts have been made recently. In a small area of $5.42 \mathrm{~km}^{2}$ the resident population (with a tendency to decrease) is nearly 37,500 (Statistics Portugal 2021), with nearly $30 \% 65$ years of age or over. Nonetheless, this is an area portrayed for its notable population fluctuation, mainly due to its link to tourism and tertiary activities. Generally, several subpopulations coexist, from sellers and buyers, to tourists, leading to other aspects as variations regarding the density and intensity in the use of spaces during different hours, days, and seasons. The (HCP is a permanent overcrowded space, busy with people and traffic not only during the day but also at night, becoming an ideal environment for the crime types analysed in this work, namely property crimes and, more specifically, thefts.

\subsection{Data and Units of Analysis}

Theft crime in the Historic Centre of Porto is analysed using the official records of the Public Security Police (PSP) that operates in the city. Between the 1st of January 2015 and the 31st of December 2019, PSP recorded a total of 31,400 crimes in the Historic Centre of 
Porto, which corresponds to an average value of 17.2 crimes per day and 523.3 crimes per month. Thefts represent $49.4 \%$ of total crimes, which corresponds to an average value of almost nine thefts per day. Table 1 shows the absolute and relative frequencies of the various theft crimes, which represents more than 100 cases in the period of observation.

\subsection{Procedure}

The method of the current study was an analysis of officially reported crime. Among the criminal occurrences registered by PSP, we selected and analysed at least 100 cases of theft crime, in the following categories: theft of opportunities/unsaved objects, theft of a motor vehicle, theft in a commercial building with a break-in, theft in a commercial building without a break-in, theft in a residential building with a break-in, theft in a residential building without a break-in, theft in motor vehicle, and theft by pickpockets (Table 1). For each individual occurrence, there was available information about the date, hour, precipitation, and temperature per day.

Table 1. Theft typologies with 100 or more cases.

\begin{tabular}{ccc}
\hline Thefts Typologies & N & Percentages \\
\hline Theft of opportunities/unsaved objects & 1202 & 11.1 \\
Theft of a motor vehicle & 422 & 3.9 \\
Theft in a commercial building with a break-in & 1051 & 9.7 \\
Theft in a commercial building without a break-in & 683 & 6.3 \\
Theft in a residential building with a break-in & 648 & 6.0 \\
Theft in a residential building without a break-in & 159 & 1.5 \\
Theft in a motor vehicle & 3956 & 36.6 \\
Theft by pickpockets & 2693 & 24.9 \\
Total & 10,814 & 100 \\
\hline
\end{tabular}

\subsection{Data Analysis}

Theft occurrences were statistically analysed using Excel and IBM ${ }^{\circledR}$ SPSS ${ }^{\circledR} 26.0$ software. Descriptive statistics (relative and absolute frequencies, and mean ranks) were calculated for the total of occurrences. Additionally, inferential statistics were computed, namely Kruskal-Wallis $(\mathrm{H})$ nonparametric test, to assess possible variations in the total number of occurrences with different seasons, temperature, and precipitation levels.

To perform the planned analysis, three variables were considered as grouping variables, addressing different factors. Variable one corresponds to seasons: autumn, winter, spring, and summer. Another variable was based on temperature, with intervals for low temperatures $\left(8^{\circ} \mathrm{C}\right.$ or less), medium $\left(8^{\circ}\right.$ to $\left.20^{\circ} \mathrm{C}\right)$, and high temperatures (above $20^{\circ} \mathrm{C}$ ). The third variable is precipitation that was categorized as: without rain, rain density of 1-4 $\mathrm{mm}$, rain density of 5-14 $\mathrm{mm}$, rain density of 15-29 $\mathrm{mm}$ and rain density superior or equal to $30 \mathrm{~mm}$.

\section{Results}

As can be seen in Table 1, theft in motor vehicle, pickpocket theft and theft of opportunities/unsaved objects were the most prevalent theft typologies in the present database, representing $36.6 \%, 24.9 \%$ and $11.1 \%$ of the registered crimes, respectively. Contrastingly, theft in a residential building without a break-in was the least prevalent crime, representing only $1.5 \%$ of the registered crimes, followed by theft of motor vehicles $(3.9 \%)$, theft in a residential building with a break-in $(6.0 \%)$, and theft in a commercial building without (6.3\%) or with a break-in (9.7\%).

Comparing the total thefts per day, there were found statistically significant differences between seasons, $\mathrm{H}(3)=22.01, p<0.001$, with pairwise comparisons showing that winter has a significantly lower total of thefts per day (winter mean rank: 496.86) than the other seasons (fall mean rank: 577.74; spring mean rank: 587.10; summer mean rank: 626.26), as can be seen in Table 2. The previous analysis was performed once again, considering 
each type of theft separately. As shown in Table 2, statistically significant differences were only found regarding theft in a residential building with a break-in, $\mathrm{H}(3)=8.82, p=0.032$, and theft in a motor vehicle, $\mathrm{H}(3)=10.51, p=0.015$. Analysing the first case, pairwise comparisons showed a significant difference between summer and all the other seasons, as the number of thefts during that period is significantly higher (summer mean rank: 49.17 vs. fall mean rank: 30.38; winter mean rank: 32.64; and spring mean rank: 32.18). Regarding the second case, pairwise comparisons demonstrated that the total of thefts per day in winter is significantly lower, compared with other seasons (winter mean rank: 203.37 vs. fall mean rank: 248.10; spring mean rank: 244.53; summer mean rank: 261). There were no statistical differences between seasons on theft of opportunities/unsaved objects, $\mathrm{H}(3)=4.81, p=0.187$; theft of a motor vehicle, $\mathrm{H}(3)=1.15 ; p<0.765$, theft in a commercial building with a break-in, $\mathrm{H}(3)=5.93, p=0.115$; theft in a commercial building without a break-in, $\mathrm{H}(3)=3.03, p=0.387$; theft in a residential building without a break-in, $\mathrm{H}(3)=0.86, p=0.652$; and theft by pickpockets, $\mathrm{H}(3)=1.00, p=0.801$. Nevertheless, based on descriptive statistics, the behavioural pattern remains the same: in every type of theft, there were a greater number of crimes in the summer compared with the number of crimes in the winter. The exception occurs in relation to theft in a commercial building with or without a break-in, of which the expression is more pronounced during winter compared with summer (Table 2).

Table 2. Differences in total of thefts per day between seasons by type of theft.

\begin{tabular}{|c|c|c|c|c|c|c|c|c|}
\hline & & \multicolumn{4}{|c|}{ Seasons } & \multicolumn{3}{|c|}{ Kruskall-Wallis Test } \\
\hline & & Fall & Winter & Spring & Summer & $H$ & df & $p$ \\
\hline Total & $\begin{array}{c}n \\
\text { Mean Rank }\end{array}$ & $\begin{array}{c}449 \\
577.74\end{array}$ & $\begin{array}{c}430 \\
496.86\end{array}$ & $\begin{array}{c}467 \\
587.10\end{array}$ & $\begin{array}{c}471 \\
626.26\end{array}$ & 22.01 & 3 & $<0.001$ \\
\hline $\begin{array}{c}\text { Theft of opportunities/unsaved } \\
\text { objects }\end{array}$ & $\begin{array}{c}n \\
\text { Mean Rank }\end{array}$ & $\begin{array}{c}32 \\
33.03\end{array}$ & $\begin{array}{c}29 \\
28.09\end{array}$ & $\begin{array}{c}22 \\
37.91\end{array}$ & $\begin{array}{c}34 \\
41.93\end{array}$ & 4.81 & 3 & 0.187 \\
\hline Theft of a motor vehicle & $\begin{array}{c}n \\
\text { Mean Rank }\end{array}$ & $\begin{array}{c}8 \\
22.31\end{array}$ & $\begin{array}{c}8 \\
24.19\end{array}$ & $\begin{array}{c}13 \\
26.50\end{array}$ & $\begin{array}{c}17 \\
21.44\end{array}$ & 1.15 & 3 & 0.765 \\
\hline $\begin{array}{l}\text { Theft in a commercial building with a } \\
\text { break-in }\end{array}$ & $\begin{array}{c}n \\
\text { Mean Rank }\end{array}$ & $\begin{array}{c}50 \\
96.80\end{array}$ & $\begin{array}{c}51 \\
82.45\end{array}$ & $\begin{array}{c}57 \\
105.71 \\
\end{array}$ & $\begin{array}{c}36 \\
106.79\end{array}$ & 5.93 & 3 & 0.115 \\
\hline $\begin{array}{l}\text { Theft in a commercial building } \\
\text { without a break-in }\end{array}$ & $\begin{array}{c}n \\
\text { Mean Rank }\end{array}$ & $\begin{array}{l}10 \\
21\end{array}$ & $\begin{array}{c}11 \\
15.05\end{array}$ & $\begin{array}{c}11 \\
22.59\end{array}$ & $\begin{array}{c}7 \\
22.29\end{array}$ & 3.03 & 3 & 0.387 \\
\hline $\begin{array}{c}\text { Theft in a residential building with a } \\
\text { break-in }\end{array}$ & $\begin{array}{c}n \\
\text { Mean Rank }\end{array}$ & $\begin{array}{c}16 \\
30.38\end{array}$ & $\begin{array}{c}14 \\
32.64\end{array}$ & $\begin{array}{c}25 \\
32.18\end{array}$ & $\begin{array}{c}15 \\
49.17\end{array}$ & 8.82 & 3 & 0.032 \\
\hline $\begin{array}{l}\text { Theft in a residential building without } \\
\text { a break-in }\end{array}$ & $\begin{array}{c}n \\
\text { Mean Rank }\end{array}$ & $\begin{array}{l}0 \\
-\end{array}$ & $\begin{array}{c}27 \\
8.83\end{array}$ & $\begin{array}{c}6 \\
7.92 \\
\end{array}$ & $\begin{array}{c}5 \\
6.20 \\
\end{array}$ & 0.86 & 3 & 0.652 \\
\hline Theft in a motor vehicle & $\begin{array}{c}n \\
\text { Mean Rank }\end{array}$ & $\begin{array}{c}135 \\
248.10\end{array}$ & $\begin{array}{c}100 \\
203.37\end{array}$ & $\begin{array}{c}115 \\
244.53\end{array}$ & $\begin{array}{l}132 \\
261\end{array}$ & 10.51 & 3 & 0.015 \\
\hline Theft by pickpockets & $\begin{array}{c}n \\
\text { Mean Rank }\end{array}$ & $\begin{array}{c}38 \\
96.24\end{array}$ & $\begin{array}{c}40 \\
89.91\end{array}$ & $\begin{array}{c}51 \\
90.15\end{array}$ & $\begin{array}{c}58 \\
98.74\end{array}$ & 1.00 & 3 & 0.801 \\
\hline
\end{tabular}

The effect of temperature on the prevalence of thefts per day was also analysed, as can be seen in Table 3. When solely considering descriptive data, there appears to be a tendency for thefts to occur more frequently at times with lower temperatures, apart from theft in a residential building without a break-in, which is of greater occurrence on days with average temperatures, and theft in a motor vehicle and theft by pickpockets occurred equally at high temperatures.

Regarding the association between the total thefts per day and the mean temperature, assessed through mean ranks comparisons, it can be observed, in Table 3, that there were no differences either when considering all types of theft combined, $\mathrm{H}(2)=4.27, p=0.118$, or when considering each type of theft separately, namely: theft of opportunities/unsaved objects, $\mathrm{H}(2)=2.03, p=0.362$; theft of a motor vehicle, $\mathrm{H}(2)=3.51, p=0.173$; theft in a commercial building with a break-in, $\mathrm{H}(2)=1.46, p=0.482$; theft in a commercial building without a break-in, $\mathrm{H}(2)=4.89, p=0.087$; theft in a residential building with a break-in, $\mathrm{H}(2)=4.95, p=0.084$; theft in a motor vehicle, $\mathrm{H}(2)=0.15, p=0.928$; theft by pickpockets, 
$\mathrm{H}(2)=0.78, p=0.677$; and theft in a residential building without a break-in, $\mathrm{Z}=7.04$, $p=0.155$.

Table 3. Differences in total of thefts per day by mean temperature, by type of theft.

\begin{tabular}{|c|c|c|c|c|c|c|c|}
\hline & & \multicolumn{2}{|c|}{ Temperature } & \multicolumn{4}{|c|}{ Kruskall-Wallis Test } \\
\hline & & Low & Medium & High & $H$ & df & $p$ \\
\hline Total & $\begin{array}{c}N \\
\text { Mean Rank }\end{array}$ & $\begin{array}{c}53 \\
650.11\end{array}$ & $\begin{array}{c}877 \\
565.45\end{array}$ & $\begin{array}{c}219 \\
595.08\end{array}$ & 4.27 & 2 & 0.118 \\
\hline $\begin{array}{l}\text { Theft of opportunities/unsaved } \\
\text { objects }\end{array}$ & $\begin{array}{c}N \\
\text { Mean Rank }\end{array}$ & $\begin{array}{c}6 \\
48.92\end{array}$ & $\begin{array}{c}92 \\
32.73\end{array}$ & $\begin{array}{c}19 \\
43.45\end{array}$ & 2.03 & 2 & 0.362 \\
\hline Theft of a motor vehicle & $\begin{array}{c}N \\
\text { Mean Rank }\end{array}$ & $\begin{array}{c}1 \\
45\end{array}$ & $\begin{array}{c}32 \\
24.19\end{array}$ & $\begin{array}{c}13 \\
20.15\end{array}$ & 3.51 & 2 & 0.173 \\
\hline $\begin{array}{l}\text { Theft in a commercial building } \\
\text { with a break-in }\end{array}$ & $\begin{array}{c}N \\
\text { Mean Rank } \\
\end{array}$ & $\begin{array}{c}16 \\
111.72\end{array}$ & $\begin{array}{c}153 \\
95.25\end{array}$ & $\begin{array}{c}25 \\
102.16 \\
\end{array}$ & 1.46 & 2 & 0.482 \\
\hline $\begin{array}{l}\text { Theft in a commercial building } \\
\text { without a break-in }\end{array}$ & $\begin{array}{c}N \\
\text { Mean Rank }\end{array}$ & $\begin{array}{c}4 \\
31.88\end{array}$ & $\begin{array}{c}32 \\
18.57\end{array}$ & $\begin{array}{c}3 \\
19.50 \\
\end{array}$ & 4.89 & 2 & 0.087 \\
\hline $\begin{array}{l}\text { Theft in a residential building } \\
\text { with a break-in }\end{array}$ & $\begin{array}{c}N \\
\text { Mean Rank }\end{array}$ & $\begin{array}{c}4 \\
35.13\end{array}$ & $\begin{array}{c}46 \\
31.87\end{array}$ & $\begin{array}{c}20 \\
43.93\end{array}$ & 4.95 & 2 & 0.084 \\
\hline Theft in a motor vehicle & $\begin{array}{c}N \\
\text { Mean Rank }\end{array}$ & $\begin{array}{c}14 \\
255.39\end{array}$ & $\begin{array}{c}371 \\
240.89\end{array}$ & $\begin{array}{c}97 \\
241.88\end{array}$ & 0.15 & 2 & 0.928 \\
\hline \multirow[t]{3}{*}{ Theft by pickpockets } & $\begin{array}{c}N \\
\text { Mean Rank }\end{array}$ & $\begin{array}{c}8 \\
97\end{array}$ & $\begin{array}{c}141 \\
92.05\end{array}$ & $\begin{array}{c}38 \\
100.62\end{array}$ & 0.78 & 2 & 0.677 \\
\hline & & \multicolumn{2}{|c|}{ Temperature } & \multicolumn{4}{|c|}{ Mann-Whitney Test } \\
\hline & & Low & Medium & High & $\mathbf{U}$ & $\mathbf{Z}$ & $p$ \\
\hline $\begin{array}{l}\text { Theft in a residential building } \\
\text { without a break-in }\end{array}$ & $\begin{array}{c}N \\
\text { Mean Rank }\end{array}$ & $\begin{array}{l}0 \\
-\end{array}$ & $\begin{array}{l}10 \\
8.5\end{array}$ & $\begin{array}{l}4 \\
5\end{array}$ & 10 & 7.040 & 0.155 \\
\hline
\end{tabular}

In order to understand if the prevalence of thefts changes with the time of day, MannWhitney tests were calculated for total theft and for each type of theft. As Table 4 shows, the pattern observed in Table 3 seems to be influenced by the time of day when crimes are committed, which invariably were reported at night with statistically significant differences for total thefts, $Z=-9.86, p<0.001$; and specifically, for theft of opportunities/unsaved objects, $Z=-4.31, p<0.001$; theft in a residential building with a break-in, $Z=-3.42$, $p<0.001$; theft in a motor vehicle, $Z=-6.49, p<0.001$; and theft by pickpockets, $Z=-4.67$, $p<0.001$. There were no statistical differences on the theft of a motor vehicle, $Z=-0.32$, $p=0.746$; theft in a commercial building with a break-in, $\mathrm{Z}=-0.89, p=0.374$; theft in a commercial building without a break-in, $\mathrm{Z}=-1.14, p=0.255$; and theft in a residential building with a break-in, $Z=-0.36, p=0.723$.

Table 4. Differences in total of thefts per day by time of day, by type of theft.

\begin{tabular}{|c|c|c|c|c|c|c|}
\hline & & \multicolumn{2}{|c|}{ Time of Day } & \multicolumn{3}{|c|}{ Mann-Whitney Test } \\
\hline & & Daytime & Night-Time & $\mathbf{U}$ & $\mathrm{Z}$ & $p$ \\
\hline Total & $\begin{array}{c}n \\
\text { Median }\end{array}$ & $\begin{array}{c}277 \\
7\end{array}$ & $\begin{array}{c}872 \\
9\end{array}$ & $73,507.50$ & -9.86 & $<0.001$ \\
\hline $\begin{array}{l}\text { Theft of opportunities/unsaved } \\
\text { objects }\end{array}$ & $\begin{array}{c}n \\
\text { Median }\end{array}$ & $\begin{array}{c}36 \\
5\end{array}$ & $\begin{array}{c}81 \\
9\end{array}$ & 731 & -4.31 & $<0.001$ \\
\hline Theft of a motor vehicle & $\begin{array}{c}n \\
\text { Median }\end{array}$ & $\begin{array}{l}7 \\
8\end{array}$ & $\begin{array}{c}39 \\
9\end{array}$ & 126 & -0.32 & 0.746 \\
\hline $\begin{array}{l}\text { Theft in a commercial building } \\
\text { with a break-in }\end{array}$ & $\begin{array}{c}n \\
\text { Median }\end{array}$ & $\begin{array}{l}34 \\
7.5\end{array}$ & $\begin{array}{c}160 \\
8\end{array}$ & 2457 & -0.89 & 0.374 \\
\hline
\end{tabular}


Table 4. Cont.

\begin{tabular}{|c|c|c|c|c|c|c|}
\hline & & \multicolumn{2}{|c|}{ Time of Day } & \multicolumn{3}{|c|}{ Mann-Whitney Test } \\
\hline & & Daytime & Night-Time & $\mathbf{U}$ & $\mathbf{Z}$ & $p$ \\
\hline \multirow{2}{*}{$\begin{array}{l}\text { Theft in a commercial building } \\
\text { without a break-in }\end{array}$} & $n$ & 22 & 17 & \multirow{2}{*}{147} & \multirow{2}{*}{-1.14} & \multirow{2}{*}{0.255} \\
\hline & Median & 6 & 7 & & & \\
\hline \multirow{2}{*}{$\begin{array}{l}\text { Theft in a residential building } \\
\text { with a break-in }\end{array}$} & $n$ & 30 & 40 & \multirow{2}{*}{312.50} & \multirow{2}{*}{-3.43} & \multirow{2}{*}{$<0.001$} \\
\hline & Median & 5.5 & 8 & & & \\
\hline \multirow{2}{*}{$\begin{array}{l}\text { Theft in a residential building } \\
\text { without a break-in }\end{array}$} & $n$ & 4 & 10 & \multirow{2}{*}{17.50} & \multirow{2}{*}{-0.36} & \multirow{2}{*}{0.723} \\
\hline & Median & 7.5 & 8 & & & \\
\hline \multirow{2}{*}{ Theft in a motor vehicle } & n & 80 & 402 & \multirow{2}{*}{8719} & \multirow{2}{*}{-6.49} & \multirow{2}{*}{$<0.001$} \\
\hline & Median & 7 & 9 & & & \\
\hline \multirow{2}{*}{ Theft by pickpockets } & $n$ & 64 & 123 & \multirow{2}{*}{2299.50} & \multirow{2}{*}{-4.67} & \multirow{2}{*}{$<0.001$} \\
\hline & Median & 7 & 9 & & & \\
\hline
\end{tabular}

Furthermore, considering rainfall when analysing all crime theft types combined or each theft type of separately (see Table 5), there were no statistically significant differences between the different precipitation periods regarding total thefts per day, $\mathrm{H}(4)=3.61$, $p=0.461$. There were no differences based on rainfall on the theft of opportunities/unsaved objects, $\mathrm{H}(4)=1.20, p=0.754$; theft of a motor vehicle, $\mathrm{H}(4)=4.24, p=0.237$; theft in a commercial building with a break-in, $\mathrm{H}(4)=6.52, p=0.164$; theft in a commercial building without a break-in, $\mathrm{H}(4)=3.03, p=0.553$; theft in a residential building with a break-in, $\mathrm{H}(4)=2.72, p=0.438$; theft in a motor vehicle, $\mathrm{H}(4)=0.76, p=0.944$; theft by pickpockets, $\mathrm{H}(4)=4.99, p=0.289$; and theft in a residential building without a break in, $\mathrm{Z}=2.86$, $p=0.383$.

Table 5. Differences in total of thefts per day considering precipitation, by type of theft.

\begin{tabular}{|c|c|c|c|c|c|c|c|c|c|}
\hline & & \multicolumn{5}{|c|}{ Rainfall } & \multicolumn{3}{|c|}{ Kruskall-Wallis Test } \\
\hline & & Without Rain & $1-4 \mathrm{~mm}$ & $5-14 \mathrm{~mm}$ & $15-29 \mathrm{~mm}$ & $\geq 30 \mathrm{~mm}$ & $H$ & df & $p$ \\
\hline Total & $\begin{array}{c}n \\
\text { Mean Rank }\end{array}$ & $\begin{array}{c}766 \\
588.06\end{array}$ & $\begin{array}{c}111 \\
539.98\end{array}$ & $\begin{array}{c}79 \\
548.34\end{array}$ & $\begin{array}{c}40 \\
538.68\end{array}$ & $\begin{array}{c}16 \\
531.78\end{array}$ & 3.61 & 4 & 0.461 \\
\hline Theft of opportunities/unsaved objects & $\begin{array}{c}n \\
\text { Mean Rank }\end{array}$ & $\begin{array}{c}84 \\
42.50\end{array}$ & $\begin{array}{c}11 \\
17.55\end{array}$ & $\begin{array}{c}8 \\
14.19\end{array}$ & $\begin{array}{c}2 \\
20.25\end{array}$ & $\begin{array}{c}12 \\
17.83\end{array}$ & 1.20 & 4 & 0.754 \\
\hline Theft of a motor vehicle & $\begin{array}{c}n \\
\text { Mean Rank }\end{array}$ & $\begin{array}{c}29 \\
24.62\end{array}$ & $\begin{array}{c}6 \\
20.67\end{array}$ & $\begin{array}{c}2 \\
16.50\end{array}$ & $\begin{array}{c}2 \\
41\end{array}$ & $\begin{array}{l}0 \\
-\end{array}$ & 4.24 & 4 & 0.237 \\
\hline $\begin{array}{l}\text { Theft in a commercial building with a } \\
\text { break-in }\end{array}$ & $\begin{array}{c}n \\
\text { Mean Rank }\end{array}$ & $\begin{array}{c}120 \\
103.28\end{array}$ & $\begin{array}{c}25 \\
85.18\end{array}$ & $\begin{array}{c}12 \\
111.42\end{array}$ & $\begin{array}{c}6 \\
90.20\end{array}$ & $\begin{array}{c}5 \\
87.58 \\
\end{array}$ & 6.52 & 4 & 0.164 \\
\hline $\begin{array}{c}\text { Theft in a commercial building without a } \\
\text { break-in }\end{array}$ & $\begin{array}{c}n \\
\text { Mean Rank }\end{array}$ & $\begin{array}{c}24 \\
19.92\end{array}$ & $\begin{array}{c}5 \\
22.80\end{array}$ & $\begin{array}{c}1 \\
17.50\end{array}$ & $\begin{array}{c}2 \\
21\end{array}$ & $\begin{array}{c}1 \\
21.17\end{array}$ & 3.03 & 4 & 0.553 \\
\hline $\begin{array}{l}\text { Theft in a residential building with a } \\
\text { break-in }\end{array}$ & $\begin{array}{c}n \\
\text { Mean Rank }\end{array}$ & $\begin{array}{c}49 \\
37.24\end{array}$ & $\begin{array}{c}6 \\
33.75\end{array}$ & $\begin{array}{c}7 \\
33.14 \\
\end{array}$ & $\begin{array}{l}0 \\
-\end{array}$ & $\begin{array}{l}1 \\
4\end{array}$ & 2.72 & 4 & 0.438 \\
\hline Theft in a motor vehicle & $\begin{array}{c}n \\
\text { Mean Rank }\end{array}$ & $\begin{array}{c}321 \\
244.07\end{array}$ & $\begin{array}{c}42 \\
229.56\end{array}$ & $\begin{array}{c}34 \\
235.57\end{array}$ & $\begin{array}{c}23 \\
274.42\end{array}$ & $\begin{array}{c}8 \\
232.56\end{array}$ & 0.76 & 4 & 0.944 \\
\hline \multirow[t]{3}{*}{ Theft by pickpockets } & $\begin{array}{c}n \\
\text { Mean Rank }\end{array}$ & $\begin{array}{c}130 \\
96.98\end{array}$ & $\begin{array}{c}16 \\
86.44\end{array}$ & $\begin{array}{c}15 \\
74.37\end{array}$ & $\begin{array}{c}4 \\
51.75\end{array}$ & $\begin{array}{c}3 \\
98\end{array}$ & 4.99 & 4 & 0.289 \\
\hline & & \multicolumn{5}{|c|}{ Rainfall } & \multicolumn{3}{|c|}{ Mann-Whitney Test } \\
\hline & & Without Rain & $1-4 \mathrm{~mm}$ & 5-14 mm & $15-29 \mathrm{~mm}$ & $\geq 30 \mathrm{~mm}$ & $\mathbf{U}$ & $\mathrm{Z}$ & $p$ \\
\hline $\begin{array}{l}\text { Theft in a residential building without a } \\
\text { break-in }\end{array}$ & $\begin{array}{c}n \\
\text { Mean Rank }\end{array}$ & $\begin{array}{c}9 \\
5.78\end{array}$ & $\begin{array}{l}0 \\
-\end{array}$ & $\begin{array}{l}0 \\
-\end{array}$ & $\begin{array}{l}1 \\
3\end{array}$ & $\begin{array}{l}0 \\
-\end{array}$ & 2 & 2.86 & 0.383 \\
\hline
\end{tabular}

However, the dichotomized observation, with and without rain, despite not reporting statistically significant differences, showed that there was a dominant pattern of theft in situations without rain except for theft of opportunities/unsaved objects (see Table 6). More specifically, there were no statistical differences on total theft, $Z=-1.89, p=0.058$; theft of opportunities/unsaved objects, $Z=-0.27, p=0.789$; theft of a motor vehicle, $Z=-0.75$, $p=0.456$; theft in a commercial building with a break-in, $Z=-1.84, p=0.066$; theft in a 
commercial building without a break-in, $Z=-0.06, p=0.954$; theft in a residential building with a break-in, $Z=-1.10, p=0.270$; theft in a residential building without a break-in, $Z=-0.40, p=0.688$; theft in a motor vehicle, $Z=-0.57, p=0.566$; and theft by pickpockets, $\mathrm{Z}=-1.14, p=0.255$.

Table 6. Differences in total of thefts per day by precipitation, by type of theft.

\begin{tabular}{|c|c|c|c|c|c|c|}
\hline & & \multicolumn{2}{|c|}{ Precipitation } & \multicolumn{3}{|c|}{ Mann-Whitney Test } \\
\hline & & without Rain & with Rain & $U$ & $Z$ & $p$ \\
\hline Total & $\begin{array}{c}n \\
\text { Mean Rank }\end{array}$ & $\begin{array}{c}766 \\
588.06\end{array}$ & $\begin{array}{c}383 \\
548.88\end{array}$ & 136,684 & -1.89 & 0.058 \\
\hline $\begin{array}{l}\text { Theft of opportunities/unsaved } \\
\text { objects }\end{array}$ & $\begin{array}{c}n \\
\text { Mean Rank }\end{array}$ & $\begin{array}{c}84 \\
42.50\end{array}$ & $\begin{array}{l}33 \\
17\end{array}$ & 1342 & -0.27 & 0.789 \\
\hline Theft of a motor vehicle & $\begin{array}{c}n \\
\text { Mean Rank }\end{array}$ & $\begin{array}{c}29 \\
24.62\end{array}$ & $\begin{array}{c}17 \\
21.59\end{array}$ & 214 & -0.75 & 0.456 \\
\hline $\begin{array}{c}\text { Theft in a commercial building } \\
\text { with a break-in }\end{array}$ & $\begin{array}{c}n \\
\text { Mean Rank }\end{array}$ & $\begin{array}{c}120 \\
103.28\end{array}$ & $\begin{array}{c}74 \\
88.12\end{array}$ & 3746 & -1.84 & 0.066 \\
\hline $\begin{array}{l}\text { Theft in a commercial building } \\
\text { without a break-in }\end{array}$ & $\begin{array}{c}n \\
\text { Mean Rank }\end{array}$ & $\begin{array}{c}24 \\
19.92\end{array}$ & $\begin{array}{c}15 \\
20.13\end{array}$ & 178 & -0.06 & 0.954 \\
\hline $\begin{array}{l}\text { Theft in a residential building } \\
\text { with a break-in }\end{array}$ & $\begin{array}{c}n \\
\text { Mean Rank }\end{array}$ & $\begin{array}{c}49 \\
37.24\end{array}$ & $\begin{array}{c}21 \\
31.43 \\
\end{array}$ & 429 & -1.10 & 0.270 \\
\hline $\begin{array}{l}\text { Theft in a residential building } \\
\text { without a break-in }\end{array}$ & $\begin{array}{c}n \\
\text { Mean Rank }\end{array}$ & $\begin{array}{c}9 \\
7.17 \\
\end{array}$ & $\begin{array}{c}5 \\
8.1\end{array}$ & 19.500 & -0.40 & 0.688 \\
\hline Theft in a motor vehicle & $\begin{array}{c}n \\
\text { Mean Rank }\end{array}$ & $\begin{array}{c}321 \\
244.07\end{array}$ & $\begin{array}{c}161 \\
236.38\end{array}$ & $25,016.5$ & -0.57 & 0.566 \\
\hline Theft by pickpockets & $\begin{array}{c}n \\
\text { Mean Rank }\end{array}$ & $\begin{array}{c}130 \\
96.98\end{array}$ & $\begin{array}{c}57 \\
87.21\end{array}$ & 3318 & -1.14 & 0.255 \\
\hline
\end{tabular}

\section{Discussion}

The time analysis of crime has been recognized as an important strategy to prevent and intervene in criminal occurrences. Seasonality is, indeed, a factor to be considered when analysing crime. Several influences have been described in the literature and, in our study, time of day (daytime vs. night-time), season, temperature and precipitation were analysed. Statistically significant differences and other results are discussed below.

Time of day was a variable assessed that showed statistically significant differences. Total thefts were more reported at night. The same was found when considering specifically the theft of opportunities/unsaved objects, theft in a motor vehicle, theft by pickpockets and theft in a residential building with a break-in. Regarding the first three types of theft, the obtained results can be explained by the smaller number of capable guardians present in the streets at night, since, according to RA theory, it is less probable that people are outdoors when weather conditions are less pleasant and the temperature at night is colder. Thus, people in the streets are more vulnerable at night.

Considering all types of theft, the present study concluded that the lowest prevalence is during winter. When considering specific theft types, theft in a residential building with a break-in, peaks during summer and theft in a motor vehicle is less frequent during winter, while the remaining types of theft showed no differences, even though the frequency pattern remained the same. These findings are not congruent with several articles reviewed, that report a higher prevalence of property crimes during winter (DeFronzo 1984; Elmer 1933, cit. in Cohen 1941; Field 1992; Quetelet's 1842, cit. Cohen 1941). However, other authors observed summer peaks, which are also reported in the present study (Linning et al. 2016). Indeed, studies focused on theft described a higher prevalence of this crime during the summer period (Cohn and Rotton 2000; McDowall et al. 2012), associating it to the increased presence of tourists (Sypion-dutkowska 2015), which is a phenomenon 
that can also be observed in Porto. Additionally, the present results are in line with the RA theory (Cohn and Rotton 2000; Rotton and Cohn 2003; Schutte and Breetzk 2018). Concerning residential building break-ins, high temperatures have been linked to a higher prevalence of this theft (DeFronzo 1984; Peng et al. 2011), because summer in Porto is the season with the most enjoyable weather conditions and, as people can spend more time outdoors due to this fact, their houses are not guarded. High temperatures have been linked to a higher prevalence of this theft (DeFronzo 1984; Peng et al. 2011). Regarding theft in motor vehicles, as people are at home more during winter due to adverse weather conditions, less vehicles can be spotted and, therefore, offenders are exposed to fewer targets.

Considering temperature, despite descriptive statistics that showed a higher theft prevalence during colder times, no statistically significant differences were reported, which is not an odd result according to other studies (Anderson et al. 1997; Cotton 1986). It should be taken into account that Porto (and, consequently, its city centre) usually does not experience extreme temperatures. Therefore, it will be interesting, in the future, to focus on criminal occurrences that were reported on the rare days when extreme temperatures were registered.

As observed regarding temperature, no statistically significant differences were reported when considering precipitation despite the dominant pattern of theft in situations without rain. The absence of association between these two variables has been reported in previous studies (Cohn and Rotton 2000; Mapou et al. 2017). Additionally, it has been described that the prevalence of property crimes is higher during periods without precipitation (Schutte and Breetzk 2018), which is seen through descriptive statistics.

The present study has some limitations that should be identified. First, it should be stressed that our database is sensitive to dark figures of crime, since not all criminal occurrences are effectively reported to the authorities because people evaluate them as minor or trivial, some remain undetected and some people may have strong reasons to not participate (Lohr 2019; Sammons and Putwain 2018). Second, we analysed a constrained timeframe, which should be extended in future studies. It should also be considered that meteorological variables may be not consistent throughout time (and due to climate changes) and may greatly differ from country to country, which can be the reason for contractions between other studies and even between this study's results and previous ones. Another potential limitation can be the focus solely on a very restricted space, namely the Historic Centre of Porto, that presents its own dynamics and metabolism, so generalizations to other cities and/or areas need to be performed with caution. Future studies should be performed to replicate our findings and to further investigate the patterns found in this work. Additionally, it is noteworthy to analyse crimes against people and other crimes against property.

Author Contributions: Conceptualization, V.A., R.L.M., G.M.O. and M.S.G.; Data curation, V.A., D.P. and M.S.G.; Formal analysis, V.A., M.M., D.P., R.L.M. and M.S.G.; Funding acquisition, R.L.M., M.S.G., A.I.S. and L.M.N.; Methodology, V.A., R.L.M., M.S.G., A.I.S. and L.M.N.; Writing-original draft, V.A., M.M. and D.P.; Writing-review and editing, V.A., M.M., G.M.O., M.S.G., A.I.S. and L.M.N. All authors have read and agreed to the published version of the manuscript.

Funding: This research was funded by Fundação para a Ciência e Tecnologia (FCT), grant number "PTDC/DIR-DCP/28120/2017" (Project LookCrim-Looking at crime: Communities and physical spaces).

Institutional Review Board Statement: Ethical review and approval were waived for this study, due to the absence of personal and/or sensitive data.

Data Availability Statement: Dataset and syntaxes are available upon request to the authors.

Acknowledgments: Authors acknowledged to Comando Metropolitano de Polícia do Porto, for providing the analysed database.

Conflicts of Interest: The authors declare no conflict of interest. 


\section{References}

Anderson, Craig. 1987. Temperature and aggression: Effects on quarterly, yearly, and city rates of violent and non-violent crime. Journal of Personality and Social Psychology 52: 1161-73. [CrossRef]

Anderson, Craig, Brad Bushman, and Ralph Groom. 1997. Hot years and serious and deadly assault: Empirical tests of the heat hypothesis. Journal of Personality and Social Psychology 73: 1213-23. [CrossRef] [PubMed]

Andresen, Martin, and Nicolas Malleson. 2013. Crime seasonality and its variations across space. Applied Geography 43: 25-35. [CrossRef]

Andresen, Martin, and Nicolas Malleson. 2015. Intra-week spatial-temporal patterns of crime. Crime Science 4: 12. [CrossRef]

Baryshnikova, Nadezhda, Shannon Davidson, and Dennis Wesselbaum. 2019. Do You Feel the Heat Around the Corner? The Effect of Weather on Crime. School of Economic Working Papers. Adelaide: University of Adelaide, School of Economics.

Breetzke, Gregory, and Ellen Cohn. 2012. Seasonal assault and neighborhood deprivation in South Africa: Some preliminary findings. Environment and Behavior 44: 641-67. [CrossRef]

Brunsdon, Chris, Jonathan Corcoran, Gary Higgs, and Andrew Ware. 2009. The influence of weather on local geographical patterns of police calls for service. Environment and Planning B-Planning and Design 36: 906-26. [CrossRef]

Ceccato, Vânia. 2005. Homicide in São Paulo, Brazil: Assessing spatial- temporal and weather variations. Journal of Environmental Psychology 25: 249-360. [CrossRef]

Cohen, Joseph. 1941. The Geography of Crime. Annals of the American Academy of Political and Social Science 217: 29-37. [CrossRef]

Cohen, Lawrence, and Marcus Felson. 1979. Social change and crime rate trends: A Routine Activity Approach. American Sociological Review 44: 588-608. [CrossRef]

Cohn, Ellen. 1990. Weather and crime. British Journal of Criminology 30: 51-64. [CrossRef]

Cohn, Ellen. 1993. The prediction of police calls for service: The influence of weather and temporal variables on rape and domestic violence. Journal of Environmental Psychology 13: 71-83. [CrossRef]

Cohn, Ellen, and James Rotton. 2000. Weather, seasonal trends, and property crimes in Minneapolis, 1987-1988: A moderator-variable time-series analysis of routine activities. Journal of Environmental Psychology 20: 257-72. [CrossRef]

Cotton, John. 1986. Ambient temperature and violent crime. Journal of Applied Social Psychology 16: 786-801. [CrossRef]

Cozens, Paul. 2007. Public health and the potential benefits of Crime Prevention Through Environmental Design. New South Wales Public Health Bulletin 18: 232-37. [CrossRef] [PubMed]

DeFronzo, James. 1984. Climate and crime: Tests of an FBI assumption. Environment and Behavior 16: 185-210. [CrossRef]

Falk, Gerhard. 1952. The influence of the seasons on the crime rate. The Journal of Criminal Law, Criminology, and Police Science 43: 199. [CrossRef]

Farrell, Graham, and Ken Pease. 1994. Crime seasonality—Domestic disputes and residential burglary in Merseyside 1988-90. British Journal of Criminology 34: 487-98. [CrossRef]

Field, Simon. 1992. The effect of temperature on crime. British Journal of Criminology 32: 340-51. [CrossRef]

Haberman, Cory, Evan Sorg, and Jerry Ratcliffe. 2017. Assessing the validity of the law of crime concentration across different temporal scales. Journal of Quantitative Criminology 33: 547-67. [CrossRef]

Hart, Rannveig, Willy Pedersen, and Torbjørn Skardhamar. 2019. Blowing in the Wind? The Effect of Weather on the Intensity and Spatial Distribution of Crime. Available online: https://osf.io/preprints/socarxiv/ qrhn4/ (accessed on 30 September 2021).

Hipp, John, Patrick Curran, Kenneth Bollen, and Daniel Bauer. 2004. Crimes of opportunity or crimes of emotion? Testing two explanations of seasonal change in crime. Social Forces 82: 1333-72. [CrossRef]

$\mathrm{Hu}$, Xiaofeng, Jiansong Wu, Peng Chen, Ting Sun, and Dan Li. 2017. Impact of climate variability and change on crime rates in Tangshan, China. Science of the Total Environment 609: 1041-48. [CrossRef]

Institute for Economics and Peace. 2021. Global Peace Index 2021. Available online: https://www.visionofhumanity.org/wp-content/ uploads /2021/06/GPI-2021-web-1.pdf (accessed on 29 September 2021).

Lab, Steven, and David Hirschel. 1988. Climatological conditions and crime: The forecast is ... ? Justice Quarterly 5: 281-99. [CrossRef]

Linning, Shannon J. 2015. Crime seasonality and the micro-spatial patterns of property crime in Vancouver, BC and Ottawa, ON. Journal of Criminal Justice 43: 544-555. [CrossRef]

Linning, Shannon J., Martin. A. Andresen, and Paul J. Brantingham. 2016. Crime seasonality: Examining the temporal fluctuations of property crime in cities with varying climates. International Journal of Offender Therapy and Comparative Criminology 61: 1866-91. [CrossRef]

Lohr, Sharon. 2019. Measuring Crime. Behind the Statistics. Boca Raton: CRC Press.

Maia, Rui Leandro, and Rui Estrada. 2017. "População, Território e Crime: Um Olhar Pelas Estatísticas Oficiais." [Population territory, and crime: An Overview of Official Statistics."]. In Crime and Safety in Contemporary Cities. Edited by Laura M. Nunes, Ana Sani, Rui Estrada, Fernanda Viana, Sónia Caridade and Rui Leandro Maia. Porto: Fronteira do Caos Editores, pp. 139-56.

Mapou, Ashley E., Derek Shendell, Pamela Ohman-Strickland, Jaime Madrigano, Qingyu Meng, Jennifer Whytlaw, and Joel Miller. 2017. Environmental Factors and Fluctuations in Daily Crime Rates. Journal of Environmental Health 80: 8-22.

Mares, Dennis, and Kenneth W. Moffett. 2019. Climate change and crime revisited: An exploration of monthly temperature anomalies and UCR crime data. Environment and Behavior 51: 502-29. [CrossRef]

McDowall, David, Colin Loftin, and Matthew Pare. 2012. Seasonal cycles in crime, and their variability. Journal of Quantitative Criminology 28: 389-410. [CrossRef] 
McLean, Iain. 2007. Climatic effects on incidence of sexual assault. Journal of Forensic and Legal Medicine 14: 16-19. [CrossRef]

Morken, Gunnar, and Olav Linaker. 2000. Seasonal variation of violence in Norway. The American Journal of Psychiatry 157: $1674-78$. [CrossRef]

Nunes, Laura, Ana Sani, Rui Estrada, Fernanda Viana, Sónia Caridade, and Rui Leandro Maia. 2017. Crime e Segurança Nas Cidades Contemporâneas [Crime and Safety in Contemporary Cities]. Porto: Fronteira do Caos Editores.

Oliveira, Gisela Marta, Diogo Guedes Vidal, and Maria Pia Ferraz. 2020. Urban lifestyles and consumption patterns. In Sustainable Cities and Communities. Encyclopedia of the UN Sustainable Development Goals. Edited by Walter Leal Filho, Anabela Marisa Azul, Luciana Brandli, Pinar Gökçin Özuyar and Tony Wall. Cham: Springer, pp. 851-60. [CrossRef]

Papaioannou, Kostadis J. 2017. "Hunger makes a thief of any man": Poverty and crime in British colonial Asia. European Review of Economic History 21: 1-28. [CrossRef]

Peng, Chen, Shu Xueming, Yuan Hongyong, and Li Dengsheng. 2011. Assessing temporal and weather influences on property crime in Beijing, China. Crime, Law and Social Change 55: 1-13. [CrossRef]

PORDATA. 2021. Base de dados de Portugal contemporâneo-Turismo [Dataset of contemporaneous Portugal—Tourism]. Available online: https: / / www.pordata.pt/Municipios (accessed on 30 September 2021).

Ranson, Matthew. 2014. Crime, weather, and climate change. Journal of Environmental Economics and Management 67: 274-302. [CrossRef]

Ratcliffe, Jerry H. 2006. A Temporal Constraint Theory to explain opportunity-based spatial offending patterns. Journal of Research in Crime and Delinquency 43: 261-91. [CrossRef]

Rotton, James, and Ellen G. Cohn. 2003. Global warming and U.S crime rates: An application of Routine Activity Theory. Environment and Behavior 35: 802-25. [CrossRef]

Sammons, Aidan, and David Putwain. 2018. Psychology and Crime. London: Routledge.

Sani, Ana, and Laura M. Nunes. 2016. "Diagnóstico de seguridad/inseguridad. Un estudio exploratorio en una comunidad urbana." ["Diagnosis of Security/Insecurity. An exploratory study in an urban community."]. Anuario de Psicología Jurídica 26: 102-6. [CrossRef]

Schutte, Francois H., and Gregory D. Breetzk. 2018. The influence of extreme weather conditions on the magnitude and spatial distribution of crime in Tshwane (2001-2006). South African Geographical Journal 100: 364-77. [CrossRef]

Sherman, Lawrence W., Patrick R. Gartin, and Michael E. Buerger. 1989. Hots spots of predatory crime: Routine Activities and the criminology of place. Criminology 27: 27-55. [CrossRef]

Sistema de Segurança Interna. 2016. Relatório Anual de Segurança Interna 2015 [National Report of Internal Security 2015]. Available online: https:/ / www.portugal.gov.pt/pt/gc21/comunicacao/documento?i=20160331-pm-rasi (accessed on 30 September 2021).

Sistema de Segurança Interna. 2020. Relatório Annual de Segurança Interna 2019 [National Report of Internal Security 2019]. Available online: https:/ / www.portugal.gov.pt/download-ficheiros / ficheiro.aspx?v=\%3D\%3DBQAAAB\%2BLCAAAAAAABAAzNDA0 sAAAQJ\%2BleAUAAAA\%3D (accessed on 30 September 2021).

Sommer, Alice J., Mihye Lee, and Marie-Abèle C. Bind. 2018. Comparing apples to apples: An environmental criminology analysis of the effects of heat and rain on violent crimes in Boston. Palgrave Communications 4: 138. [CrossRef]

Statistics Portugal. 2021. Censos 2021: Resultados Preliminaries. Available online: https://www.ine.pt/scripts/db_censos_2021.html (accessed on 30 September 2021).

Stevens, Heather R., Paul J. Beggs, Petra L. Graham, and Hsing-Chung Chang. 2019. Hot and bothered? Associations between temperature and crime in Australia. International Journal of Biometeorology 63: 747-62. [CrossRef]

Sypion-dutkowska, Natalia. 2015. Temporal patterns of urban crime. Journal of Geography, Politics and Society 5: 37-45. [CrossRef]

Wu, Connor Y. H., Harry F. Lee, and Hua Liu. 2019. Effect on temperature and precipitation change on crime in the metropolitan area in Virginia, USA. Asian Geographer 37: 17-31. [CrossRef]

Yan, Yul Yee. 2004. Seasonality of property crime in Hong Kong. The British Journal of Criminology 44: 276-83. [CrossRef] 